\title{
IMPROVE MATHEMATICAL LEARNING CREATIVITIES OF JUNIOR HIGH SCHOOL STUDENTS THROUGH SNOWBALL THROWING TYPE OF COOPERATIVE LEARNING MODEL
}

\author{
Moch Hasbi Ridlo Ma'sum ${ }^{1}$, Nurkolis ${ }^{2}$ \\ ${ }^{1}$ IKIP Siliwangi, Cimahi \\ ${ }^{2}$ MA Teladan Al-Kalam Cianjur \\ 1harimasu1408@gmail.com, ${ }^{2}$ nurkolis1327@gmail.com
}

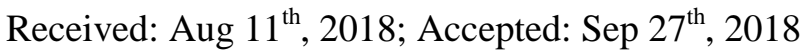

\begin{abstract}
The overall success of the study included the level of student creativity increased, seen from the four creative indicators namely fluency (fluency), flexibility (flexibility), originality (authenticity) and elaboration (decomposition) which always experienced an increase in each cycle. In line with this research is based on problems found in schools, especially in mathematics learning needs to be pursued a learning strategy, one of which is using the cooperative type snowball throwing learning model. Based on the results of the research evaluation, it can be concluded from the results of the study that snowball throwing models can enhance students' creativity, provide a good and pleasant atmosphere, and produce a positive response to mathematics learning activities.
\end{abstract}

Keywords: Mathematical Learning Creativity and Cooperative Learning Model Type Snowball Throwing

\begin{abstract}
Abstrak
Keberhasilan penelitian secara keseluruhan diantaranya tingkat kreativitas siswa meningkat, dilihat dari keempat indikator kreatif yaitu fluency (kelancaran), fleksibility (keluwesan), originality (keaslian) dan elaboration (penguraian) yang selalu mengalami peningkatan pada setiap siklusnya. Sejalan dengan penelitian ini didasarkan pada permasalahan yang ditemukan di sekolah khususnya pada pembelajaran matematika perlu diupayakan suatu strategi pembelajaran, salah satunya adalah menggunakan model pembelajaran tipe kooperatif snowball throwing. Berdasarkan hasil evaluasi penelitian dapat diperoleh kesimpulan dari hasil penelitian bahwa model snowball throwing dapat meningkatkan kreativitas siswa, memberikan suasana yang baik dan menyenangkan, serta menghasilkan respon yang positif terhadap kegiatan pembelajaran matematika.
\end{abstract}

Kata Kunci: Kreativitas Belajar Matematika dan Model Pembelajaran Kooperatif Tipe Snowball Throwing

How to Cite: Ma'sum, M.H.R., Nurkolis (2018). Improve Mathematical Learning Creativities of Junior High School Students Through Snowball Throwing Type of Cooperative Learning Model. JIML, 1 (3), 302-306.

\section{INTRODUCTION}

One effort that can be done to develop the quality of human resources is by developing creativity that can be recognized and stimulated early. Creativity in learning is important. Slameto (2003) sid that creative relates to finding something, about something that produces something new by using something that already exists. Likewise in learning mathematics because mathematics is rich in various kinds of problems arising from mathematical problems, so it needs to be found a solution. 
According to Guilford (Munandar, 1992), a form of creative thinking is the ability to see various possibilities for solving a problem. Creative students will be able to find new ideas and ways to solve the given questions. Such conditions are very supportive of the achievement of learning objectives, so that the material can be conveyed well.

If all students are trained to be able to think creatively, then the possibility of achieving the goals of learning will be even greater. Therefore the learning model used in PBM must be appropriate. In learning, the teacher must be able to create a condition that allows students to be able to learn and must also strive to generate student learning initiatives.

In cooperative learning students no longer study individually, but are directed to be able to group with other students, so they can be trained to discuss, work together and help each other in completing the assignments. According to Slavin (2005) , Cooperative learning refers to various kinds of teaching methods, where students work in small groups to help each other in learning subject matter.

In snowball throwing learning, students in groups are directed to be able to make math problems, and solve problems that have been made by the other groups as well as possible. The application of this model in mathematics learning, involves students to be able to play an active role with the guidance of the teacher, in order to improve students' ability to understand mathematics learning material. Through the snowball throwing model, it is expected to attract students' attention, increase the enthusiasm of students' learning, and increase the creativity of students' mathematics learning. Increasing creativity with the snowball throwing learning model can be trained from the activities of students making problems, they are directed and demanded to be creative to create various questions that are different from the other groups. If students are trained to be able to think creatively, then the possibility of achieving the goals of learning will be even greater.

Creativity in learning is important. Creativity according to Munandar (1992) that creativity is an ability that reflects fluency, flexibility (flexibility) and originality in thinking and the ability to elaborate (develop, enrich, specify) an idea. Therefore, the teacher must practice a lot of the creativity of his students, so that they can create new ideas to solve learning problems. According to Slameto (2003), Teachers must give freedom to students to find their own solutions, so as to foster a sense of responsibility and great confidence. The snowball throwing model is expected to foster a sense of responsibility towards students, and train them to be creative individuals.

In the problems found, the use of snowball throwing is expected to form creative students and assist students in achieving the goals of the learning provided.The Introduction presents the purpose of the studies reported and their relationship to earlier work in the field. It should not be an extensive review of the literature. Use only those references required to provide the most salient background to allow the readers to understand and evaluate the purpose and results of the present study without referring to previous publications on the topic.

\section{METHOD}

The research method that will be used is qualitative research. Qualitative research will be used in the form of Classroom Action Research (CAR). The CAR is made up of three cycles, each cycle consisting of three meetings. Two meetings are learning actions using the snowball throwing type cooperative learning model, which is the presentation of group learning models by means of students creating math problems, which are then formed by paper balls that are thrown and completed by their friends as well as possible. Then one more meeting was used for the cycle test and filled the attitude scale questionnaire in the last cycle.

In order for this study to be directed towards the goals expected, the research model used in this study was CAR Kemmis and Mc Taggart's model which was described by Arikunto and Suhardjono (2010) with the aim of increasing the creativity of mathematics learning for junior high school students. The 
304 Ma'sum, M.H.R., Nurkolis.. Improve Mathematical Learning Creativities Of Junior High School Students Through Snowball Throwing Type Of Cooperative Learning Model.

instruments used included (a) tests, (b) attitude scale, (c) journals, (d) observation sheets and (e) interviews.

\section{RESULTS AND DISCUSSION}

\section{Results}

Table 1. The Precentage of Creativity Indicators Average in Each Cycle

\begin{tabular}{cccc}
\hline \multirow{2}{*}{ Indicator } & \multicolumn{3}{c}{ Percentage $(\%)$} \\
& Cycle I & Cycle II & Cycle III \\
\cline { 2 - 4 } & 88.46 & 89.11 & 91.66 \\
\hline Fluency & 81.41 & 82.69 & 83.97 \\
\hline Fleksibility & 72.43 & 75.00 & 78.84 \\
\hline Originality & 68.59 & 75.00 & 78.20 \\
\hline Elaboration & & &
\end{tabular}

Table 1. shows that all creativity indicators increased in each cycle. The increasing of elaboration was the best.

Tabel 2. Level of Student's Creativity

\begin{tabular}{ccccccc} 
& \multicolumn{5}{c}{ Numbers of Students and Percentage } \\
\cline { 2 - 7 } Level & \multicolumn{2}{c}{ Cycle I } & \multicolumn{2}{c}{ Cycle II } & \multicolumn{2}{c}{ Cycle III } \\
\cline { 2 - 7 } & $\mathrm{N}$ & $(\%)$ & $\mathrm{N}$ & $(\%)$ & $\mathrm{N}$ & $(\%)$ \\
\hline High & 29 & 74.35 & 32 & 82.05 & 37 & 94.87 \\
\hline Medium & 10 & 25.64 & 7 & 17.94 & 2 & 5.12 \\
\hline Low & 0 & 0 & 0 & 0 & 0 & 0 \\
\hline
\end{tabular}

Students had good level of student's creativity. Table 2 describes that there's noone in low level of student's creativity.

Tabel 3. The Percentage of Student's Perception in Each Cycle

\begin{tabular}{ccccccc} 
& \multicolumn{4}{c}{ Numbers of Students and Percentage } \\
\cline { 2 - 8 } Perception & \multicolumn{2}{c}{ Cycle I } & \multicolumn{2}{c}{ Cycle II } & \multicolumn{2}{c}{ Cycle III } \\
\cline { 2 - 8 } & $\mathrm{N}$ & $(\%)$ & $\mathrm{N}$ & $(\%)$ & $\mathrm{N}$ & $(\%)$ \\
\hline Positive & 31 & 79.48 & 35 & 89.74 & 39 & 100 \\
\hline Negative & 8 & 20.51 & 4 & 10.25 & 0 & 0 \\
\hline
\end{tabular}

Based on table 3, the positive perception increased from the first cycle until the third cycle. This perception shows that learning through snowball throwing made students could enjoy the lesson.

\section{Discussion}

\section{Student Learning Creativity}

Test analysis to determine the level of creativity calculated from the results of creative indicators in each cycle. Creative indicators consist of fluency (smoothness), flexibility (flexibility), originality (authenticity) and elaboration (decomposition). Students who have high creativity must have four good creative indicators. The level of creativity can be trained, researchers try to use a snowball 
throwing model to increase the level of student creativity. With a snowball throwing model students are trained creatively to make questions and answer questions from their friends.

The results of the analysis of the level of creativity of each cycle of four indicators of fluency, flexibility, originality and elaboration have increased. It can be seen the calculation of the level of creativity in Appendix C. The level of creativity of each cycle is grouped into creative criteria, namely high, medium and low. Each cycle of students' creative criteria also increases. From the results of the analysis of the level of creativity through cycles I, II, and III, it can be concluded that through snowball throwing models can improve the creativity of learning of seventh grade junior high school students in mathematics learning.

\section{Student Learning Atmosphere}

Student learning atmosphere is seen from the results of daily journals and student observation sheets. From the results of the journal, student comments that are positive and negative can be known. Journal results for each cycle on positive comments increase while negative comments decrease. This means that student comments are better for the use of snowball throwing models.

From the observations of students each cycle also experienced an increase. Students' attitudes and learning atmosphere improve. So from the results of the journal analysis and observation sheets it can be concluded that the atmosphere of mathematics learning using a snowball throwing model can create a good, interesting, active and fun learning atmosphere

\section{Student Response}

Student responses are measured by attitude scale and interview given at the end of the third cycle. The attitude scale consists of positive and negative statements with choices of answers Strongly Agree (SA), Agree (A), Disagree (D), and Strongly Disagree (SD). From the results of the calculation of the attitude scale that can be seen in Appendix C, that the student response obtained at 3.07 with an interpretation of .52 .5 is positive.

Student interview results obtained positive student responses to learning using snowball throwing, students like to learn to use snowball throwing, because they can practice creatively in making and working with other friends. So from the results of questionnaires and interviews it can be concluded that the students' response to the snowball throwing learning model is positive.

\section{CONCLUSION}

Based on the results of the analysis of research on mathematics learning by using snowball throwing learning models, in an effort to improve student learning creativity, some conclusions can be drawn as follows: (1) Learning mathematics using a snowball throwing type cooperative model can help improve student learning creativity, as evidenced by the test results towards creative indicators such as fluency (smoothness), flexibility (flexibility), originality (authenticity) and elaboration (decomposition) that each cycle has increased. (2) Learning mathematics using the snowball throwing type cooperative model can create an atmosphere of learning that is good, interesting, active and fun, as evidenced by the results of student journals that mostly comment positively and results from observations that produce a better atmosphere in each cycle. (3) Learning mathematics using a snowball throwing model can produce a good response from students, in accordance with the results of the attitude scale questionnaire which states a positive response.

\section{REFERENCES}

Arikunto, S., Suhardjono., S. (2010). Penelitian Tindakan Kelas. Jakarta: Bumi Aksara. 
306 Ma'sum, M.H.R., Nurkolis.. Improve Mathematical Learning Creativities Of Junior High School Students Through Snowball Throwing Type Of Cooperative Learning Model.

Munandar, U. (1992). Mengembangkan Bakat dan Kreativitas Anak Sekolah. Jakarta: Gramedia.

Slameto. (2003). Belajar dan Faktor-faktor yang Mempengaruhinya. Jakarta: Rineka Cipta. Slavin, R. E. (2005). Cooperative Learning Teori Riset dan Praktik. Bandung: Nusa Media. 